\title{
European Parliament rejects bid to stem confusion over gene patents
}

London. Attempts to lay down clear guidelines on whether human genes and transgenic animals can be patented have been rejected by the European Parliament. Last week, the parliament refused by 240 votes to 188, with 23 abstentions, to approve draft legislation aimed at tightening rules on patenting biotechnology products in member states of the European Union (EU).

As a result, the fate of applications for such patents will remain subject to the interpretation of the European Patent Convention (EPC), to which almost all EU states are signatories. In principle, this allows for patents on both genes and animals. But the convention is ambiguous, as it explicitly excludes patents on animal (and plant) varieties, and on any invention considered to threaten l'ordre publique, loosely translated as public morality.

Europe's biotechnology industry had seen the process of harmonizing patent legislation between the $15 \mathrm{EU}$ member states as an opportunity to reduce such ambiguity. They point

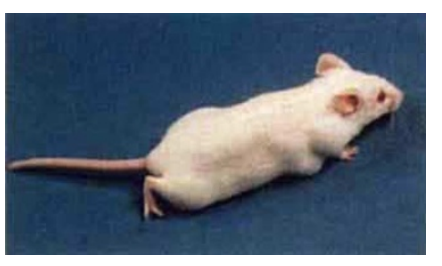

New targets: activists are planning challenges to patents on the neem tree (above) and Harvard's 'oncomouse' (left).

Doyle, an executive director of Zeneca Ltd, and vice-chairman of the Senior Advisory Group Biotechnology to the Federation of European Chemical Industries. "It is a very negative signal to the world at large about the worthwhileness of investing in biotechology in Europe.'

Indeed, Doyle describes last week's vote - the first in which the parliament has used

\section{IMAGE UNAVAILABLE FOR COPYRIGHT REASONS}

out that the convention was signed in 1973, before the full commercial significance of genetic engineering became apparent.

They also point out that, in principle, the failure of a seven-year effort to achieve this goal is unlikely in itself to have a major impact. Indeed, after a series of compromises aimed at reaching a single text capable of securing the necessary political support, an increasing number of companies were beginning to feel that they would be better off if the whole process was dropped.

In practice, however, many senior figures in the biotechnology industry fear that the outcome of the parliamentary vote will increase public pressure for greater regulation - and undermine efforts to reduce such regulation, which they claim is holding back European biotechnology in its competition with the United States and Japan.

"The outcome was appalling," says Peter its new powers under the Maastricht Treaty agreed in 1992 to veto legislation approved by the EU's principal intergovernmental body, the Council of Ministers - as an "indictment" of the parliament's powers. Giving in to pressure groups "is not democracy", he says.

But while the biotechnology industry is licking its wounds, the decision has given a political boost to pressure groups that have been using the debate about patenting to express criticism of genetic engineering and the way that it is used.

Many of them say that the vote's impact will not be confined to Brussels, but will provide support for anti-patenting campaigns across the world, ranging from farmers' groups in India protesting against the implications of the intellectual property provisions of the General Agreement on Tariffs and Trade, to debates in the US Congress

\section{CERN asks Japan for support to build LHC}

Tokyo. Christopher Llewellyn Smith, director-general of the European Laboratory for Particle Physics (CERN) in Geneva, Switzerland, last week officially asked Japan's minister of education, Kaoru Yosano, for his country's cooperation in the construction of CERN's planned Large Hadron Collider (LHC).

The move follows numerous unofficial approaches by CERN officials dating back to June 1992 (see Nature 357, 429; 1992). The ministry has said that it will discuss
Llewellyn Smith's request before deciding whether to ask for funding in the budget request for fiscal year 1996, due at the end of August.

After his meeting with Japanese officials, Llewellyn Smith declined to comment on the negotiations beyond saying they were "positive", and that they had covered both Japan's potential contribution to LHC construction costs and the possibility that it might be given associate membership to CERN. David Swinbanks about the ethics of patenting life-forms.

"This decision will have a multiplier effect, and will certainly have an impact on our work; it is a great victory," says Jeremy Rifkin of the Foundation for Economic Trends in Washington DC, which is planning to launch a new campaign next month, backed by prominent community leaders, against patents on animals and human organisms.

Under the rules of the Maastricht Treaty, the parliamentary veto of a compromise text - agreed in January between its own representatives and : those from the Council of Ministers

i - means that the whole attempt to harmonize national legislation on biotechnology patents between EU member states has been aborted.

The Commission will now have to decide whether to begin again from scratch. But industry became increasingly lukewarm about the draft directive as various revisions were introduced to meet the parliament's concerns about ethics. At the same time, decisions by the European Patent Office (EPO) have frequently gone in industry's favour, and many now doubt whether a new directive would be helpful.

A further effect of the vote will be to shift the focus of controversy back to debates on individual applications passing through the EPO. "The front will now move to where it should have been all the time," says Linda Bullard, a lobbyist with the Greens in Brussels who campaigned heavily against the compromise text.

According to Bullard, three particular cases will now become the target of legal protests: the granting of a patent to the Howard Florey Institute covering the gene for the production of relaxin, to the US seed company W. R. A. Grace on the products of the Indian neem tree, and to Harvard University and the Dupont chemical company on the so-called oncomouse.

In each case, the parliamentary vote may play a significant part in swaying the EPO's decision on whether a particular application contravenes l'ordre publique. Last month, for example, it rejected this argument in turning down an appeal against the relaxin patent.

A separate appeal against the oncomouse patent is being mounted by animal welfare groups such as Compassion in World Farming and the British Union Against Vivisection, whose own lobbying helped to defeat last week's proposed legislation. This appeal will be heard by the EPO in November, and is being widely seen as a test case for other patent applications on transgenic animals.

David Dickson 